\title{
A DECLARATION OF PERMANENT INCAPACITY TO SERVE AS A CONDITION FOR COMPULSORY DISMISSAL OF A POLICE OFFICER FROM SERVICE
}

\begin{abstract}
The article analyzes the issue of permanent incapacity to work, which is the premise for obligatory dismissal of police officers from service. The reflections are aimed at showing to what extent the statutory regulations in this area should be considered justified. Questions were raised as to whether the catalog of reasons for dismissing an officer from service is a closed catalog. The author referred to the above issue more broadly, indicating whether this catalog exhausts all situations that may constitute the basis for termination of the employment relationship of a police officer, making a distinction in this respect when the employment relationship ends as a result of an act performed by one of the parties to the employment relationship and cases where termination of employment occurs ex lege. The author referred to the nature of the personnel order which was the basis form dismissal from the service of a police officer due to the fulfillment of the condition of permanent incapacity for work confirmed by a medical certificate.

The article discusses in detail the issues related to dismissal from service, the admissibility and obligatory application of the consequences in the event of prerequisites, as well as the legitimacy of such a solution. The issues of finality and validity of the decision of the medical commission, which constitute the basis for issuing a personal order on dismissal from service, were also discussed.
\end{abstract}

Słowa kluczowe: funkcjonariusz policji, zatrudnienie administracyjnoprawne, zatrudnienie niepracownicze, służba w policji, decyzja administracyjna, rozkaz personalny, ustanie stosunku zatrudnienia

Keywords: police officer, administrative and legal employment, non-employee employment, service in the police, administrative decision, personnel order, termination of employment

ASJC: 3308, JEL: K31

The employment relationship of police officers, similarly to officers of other militarized services, is a non-employment relationship of an administrative and legal nature. 
The starting date of service is determined by a personal order on appointment. Thus, employment takes place on the basis of a formally unilateral legal act. Substantially, however, it is a bilateral activity, because the qualification procedure for service is initiated by the person concerned himself, by submitting a declaration of will to join the ranks of the police. Moreover, the officer implicitly consents to the act of appointment by proceeding with the performance of duties.

Detailed rules for the performance of service and the establishment and termination of the employment relationship are regulated by the provisions of the Act of 6 April 1990 on the Police (Dz.U. 2020, item 360 consolidated text, as amended, hereinafter referred to as: the Police Act), as well as in the ordinance on detailed rights and obligations and the course of service of police officers (the Ordinance of the Minister of the Interior of 14 May 2013 on the detailed rights and obligations and the course of police service, Dz.U. 2020, item 1113 consolidated text, hereinafter referred to as: the Ordinance on the service of policemen).

Article 41 of the above-mentioned the Police Act contains a catalog of reasons which justify the dismissal of a police officer from service. Dismissal from service is synonymous with the termination of the service relationship. The employment relationship of a police officer may be terminated both for reasons attributable to the employee and for reasons beyond their control. The legislator formulated a closed of premises constituting the basis for terminating the employment relationship with a police officer. These conditions either oblige the employing entity to terminate the employment relationship or give the right to make such a decision.

This article deals with one of the conditions which constitute the obligatory basis for terminating the employment relationship with an officer. The reflections are aimed at showing to what extent the statutory regulations in this area should be considered justified.

Despite the fact that the legislator indicated a numerus clausus of grounds justifying the dismissal of an officer from service, it cannot be assumed that the Police Act contains all possible grounds, the existence of which leads to the termination of the employment relationship of a police officer. Although it is in vain to look for a reference in the provisions of the Police Act to Art. 631 of the Labour Code Act of 26 June 1974 (Dz.U. 2020, item 1320 consolidated text, as amended, hereinafter referred to as: the Labour Code) ${ }^{1}$ or an analogous regulation in the provisions of that Act, it should be recognized, however, that in the event of the death of a police officer, the service relationship expires. From the argument a rerum natura, the employment relationship cannot last in the event of the death of the employed entity. Then it should be assumed that the ex lege legal bond ceases to exist.

1 For example, in the case of the Act of 12 October 1990 on the Border Guard (Dz.U. 2020, item 305 consolidated text, as amended), where in Art. 45a, the legislator indicated that the employment relationship of a Border Guard officer expires on the day of his death. Similarly, Art. 43a of the Act of 24 August 1991 on the State Fire Service (Dz.U. 2020, item 1123 consolidated text). 
Do the above conclusions not contradict the statement about a closed catalogue of conditions justifying the dismissal of an officer from service? The answer to this question should definitely be given in the negative. For clarification purposes, it is helpful to define key terms such as termination of employment, dismissal and termination of employment. The meaning of the term of termination of employment includes both the form of dismissal from service and the symptoms of termination of the employment relationship. It can be said that any circumstance that consequently leads to the termination of the employment relationship will fall within the concept of the grounds for termination of the employment relationship. These are both forms for which the activity of any of the entities of the employment relationship is needed-either the employing or employed entity, or forms that occur without externalized will and human activity, aimed at achieving the effect of terminating the legal relationship, of which speech. The first of the mentioned groups is the sphere of dismissal from service or leaving the service-depending on who the initiative to terminate the employment relationship comes from. The second is the formula for the termination of the employment relationship, which occurs ex lege-by virtue of the law itself.

Therefore, while it should be stated that the conditions justifying the dismissal of a police officer from service were formulated by the legislator in the form of a numerus clausus - a closed catalogue, the conditions that lead to the termination of the police officer's service relationship have not been listed exhaustively. At this point, the de lege ferenda postulate should be formulated to supplement the resulting legal gap by the legislator, following the example of the Labour Code or other official pragmatists, to include the raised premise expressis verbis in the provisions of the act, as a premise under which it should be assumed that the relationship is terminating legal business relationship.

Moving on to the analysis of the premise boiling down to the declaration of permanent incapacity for service, I will begin by outlining the reasons why the legislator is obliged to terminate the employment relationship of a police officer in the event of the disclosure of the above circumstances.

The aim of the regulation is to ensure the possibility of removing from the group of police officers those who, due to their health condition, cannot perform the service in an efficient and proper manner. As rightly emphasized by the Voivodeship Administrative Court in Łódź (judgment of the Voivodeship Administrative Court in Łódź of 24 May 2019, III SA/Ed 189/19, LEX 2679202), the norm expressed in the provision in question boils down to ensuring the possibility of removing police officers from the group of officers whose health condition makes it impossible to perform the service and properly perform the entrusted tasks.

Thus, the legislator provided for the possibility of dismissing from service those who, for objective, no-fault reasons, cannot continue to fulfil their duties in an appropriate manner. Dismissal from service in this case, as in any other, listed in Art. $41 \mathrm{sec} .1$ of the Police Act is carried out by issuing a personal order. For the sake of order, it should be added that in the Police Act, the legislator uses the term "order," clarifying in the Ordinance on the service of policemen that matters related to establishing, 
shaping and terminating the service relationship policemen are carried out on the basis of a personal order (Korcz-Maciejko 2013). The above administrative act, despite its specific name, constitutes an administrative decision within the meaning of Art. $1 \mathrm{sec} .1$ and Art. $104 \$ 1$ of the Act of 14 June 1960 Code of Administrative Procedure (Dz.U. 2021, item 735 consolidated text, hereinafter referred to as: the Code of Administrative Procedure).

Returning to the merits, a policeman shall be dismissed from service in the event of a medical commission certifying that he is permanently incapable of service. The concept of permanent incapacity for service is reduced to the diagnosis of an illness or disability which prevents the service from being performed (Art. 6 sec. 2 point 5 of the Act of 28 November 2014 on medical boards subordinate to the minister competent for internal affairs, Dz.U. 2020, item 398 consolidated text, hereinafter referred to as: the Act on medical boards). The provision of art. $41 \mathrm{sec}$. 1 of the Police Act may not be interpreted extensively, therefore only the judgment referred to in Art. 6 sec. 2 point 5 of the Act on medical boards, i.e., finding al illness or a handicap which prevents the performance of service. The certificate of permanent incapacity to perform service in the position held within the meaning of Art. $6 \mathrm{sec}$. 2, point 2, which concerns the diagnosis of disease or disabilities that reduce the physical or mental capacity to serve and do not allow the service in the position held. These diseases or disabilities do not, however, constitute an obstacle to continue serving in a different position. According to the wording of the cited provision, in such a case, the medical commission determines what conditions of service are contraindicated for the officer.

For the sake of order, it is necessary to explain the beginning of the meaningful concepts of "handicap" and "disease," the help of the legislator. There are no manual search terms in the law. The measure that they are used in colloquial their point. Following the PWN dictionary the meaning of the word "disease" comes down to a malfunction, and "handicap" in other words is congenital or acquires a physical or mental defect. Each decision, as well as the handicap, may decrease in terms of a reduced price or mental health, which has a direct impact on the decision to perform tasks for an officer. The statement of permanent incapacity for service is tantamount to awarding the officer to category $\mathrm{C}$, qualifying the officer as permanently incapable of service.

In the Act on medical boards, the procedure for lodging appeals against the decisions of district medical commissions was described. Under Art. $43 \mathrm{sec} .1$ the appeal shall be submitted to the Central Medical Commission, via the regional medical commission, within 14 days. However, it is in vain to look for the expressis verbis standard of the final nature of the decisions of the Central Medical Commission. Such regulations are included, for example, in $\$ 26 \mathrm{sec}$. 1 point 2 of the Ordinance of the Prime Minister of 7 January 2015 on adjudication by medical boards reporting to the Head of the Internal Security Agency and the Head of the Foreign Intelligence Agency (Dz.U. 2015, item 47). Such a standard was also mentioned in $\$ 31 \mathrm{sec}$. 4 of the no longer binding Ordinance of the Minister of the Interior of 9 July 1991 on the 
properties and procedure of medical boards subordinate to the Minister of the Interior (Dz.U. 1991, No. 79, item 349). ${ }^{2}$

However, bearing in mind that the current act on medical boards does not provide for the appeal procedure against the decisions of the Central Medical Commission, it should be assumed that they are final. Decisions issued by committees constitute administrative decisions within the meaning of Art. 104 of the Code of Administrative Procedure medical boards subordinate to the minister competent for internal affairs, determining the candidate's ability to serve in the Police, are, in such a case, public administration bodies. Therefore, the final decisions of medical boards regarding the assessment of the health condition of a specific person may be appealed to the administrative court (judgment of the Voivodeship Administrative Court in Warsaw of 31 January 2018, II SA/Wa 1069/17, LEX 2491821) pursuant to Art. 235 of the Code of Administrative Procedure lodged within 30 days from the date of receipt of the decision. The complaint is submitted through the Central Medical Commission.

We deal with the final decision of the medical commission when no appeal has been lodged with the Central Medical Commission within 14 days, or when, as a result of such an appeal, the Central Medical Commission has issued a decision (judgment of the Supreme Administrative Court of 18 February 2016, I OSK 2849/14, LEX 2080560). It will be final. On such basis, proceedings may be initiated to dismiss an officer from service. The decision of the medical commission, which is the basis for dismissal from service, should be final. The concept of legality, on the other hand, is related to the inability to appeal to a court. The attribute of legality also have judgments against which a party, pursuant to Art. 127a $\$ 2$ of the Code of Administrative Procedure waived the right to appeal.

\section{The period of protection}

The obligation to be released from service in the event of permanent incapacity for service by a medical commission is conditional. In connection with the wording of Art. 43(1) of the Police Act, this provision will apply when the 12-month period has elapsed since cessation of service due to illness. Therefore, the dismissal can only take place after the expiry of the 12-month protection period (judgment of the Voivodeship Administrative Court in Lublin of 19 July 2011, III SA/Lu 196/11, LEX 853004). This period should be counted from the beginning of the absence, as a result of which the police officer ceased to perform official duties due to illness.

When introducing a protection period, the legislator linked the passage of time with the date of dismissal of a policeman from service, and not with the date of the decision. Thus, a personal order, the basis of which is a final and binding decision of

2 Repealed with the entry into force of the Ordinance of the Minister of the Interior of 19 December 2014 on medical boards subordinate to the minister competent for internal affairs, Dz.U. 2014, item 1894. 
the commission on permanent incapacity for service, may be issued earlier, within 12 months. The date of termination of the service relationship indicated in the personal order must be determined after the guaranteed period.

\section{The method of calculating the beginning of the protection period}

In order to establish the starting date of the period referred to by the legislator in Art. $43 \mathrm{sec} .1$ of the Police Act, two cases should be considered.

The first of the situations takes place when the statement of permanent incapacity for service was issued during the police officer's absence due to illness. The period of protection then begins on the day the service was stopped for this reason, and therefore from the first day of continuous sickness absence. If the police officer has not ceased service before the decision is issued, the period of protection will start on the day on which the policeman stops service due to the disease stated in the decision. Pursuant to $\$ 24$ of the Ordinance on the service of policemen, the duty of the supervisor in charge of personal matters to release a policeman from the duty to which the decision relates to the period up to the date of dismissal from the service was imposed.

It should be assessed how the interruption of the 12-month period should be assessed by the applicant's declaration of readiness to undertake the service. In Art. $71 \mathrm{~b} \mathrm{sec} .1$ of the Police Act, the legislator stipulates that in order to determine the ability to perform the tasks in the position held, an officer is obliged to undergo control tests, the date of which is indicated in the referral. Until the amendment to the Police Act (the Act of 1 December 2017 amending certain acts in the field of occupational health and safety, Dz.U. 2016, item 1955) entered into force, it was in vain to look for legal grounds to formulate the obligation to send police officers for control tests. The above issue is regulated by the provisions of the Labour Code, which, however, as a rule, does not apply to administrative and legal relations. Only, in connection with the wording added in Art. 1 of the Act, the provision of Art. 71a sec. 6 in the Police Act, the legislator introduces appropriate application of the provisions of the Labour Code to issues related to occupational safety and health. Therefore, in relation to the control tests of officers, the provision of Art. $229 \$ 2$ of the Labour Code, which requires referral to check-up in the event of absence due to illness and lasting more than 30 days. Practice shows that the obligation to refer to control tests is sometimes desirable referring a policeman for examination to a medical commission. Considering the fact that the scope of examinations conducted by medical boards exceeds the scope of control examinations, and as indicated by the legislator, the provisions of the Labour Code are to be applied accordingly, and not directly, the above practice is undoubtedly permissible under applicable law.

Therefore, returning to the merits, the mere declaration of the readiness for service does not interrupt the period specified in Art. $43 \mathrm{sec} .1$ of the Police Act. This is only done by actually entering the service. 
Another case is the issue of a medical certificate, which must confirm both the fact and the period of incapacity for work (Art. 55 of the Act of 25 June 1999 on cash benefits from social insurance in the event of sickness and maternity, Dz.U. 2021, item 1133 consolidated text). However, the lack of a sick leave for individual days of the officer's absence does not per se mean the interruption of the protection period. The Supreme Administrative Court made a similar statement in the judgment of 20 November 2019 (I OSK 3291/18, LEX 2768821), in which it stated that the fact that the fact that he was illegitimate to sick leave does not contradict in itself that the officer is already fit for service. Thus, ad exemplum, the first day after a long absence due to illness, on which the officer is obliged to perform medical check-ups, and which is also the day on which the absence from work is justified by the necessity to perform them, does not interrupt the period referred to above. Similarly, if the period of absence due to illness is interrupted by an absence due to another reason, for example resulting from the use of a planned vacation leave by an officer, such a state of affairs does not involve the police officer's actual return to service, in particular if the officer was already recognized as unfit for service and therefore the period of protection is not interrupted (judgment of the Voivodeship Administrative Court in Gliwice of 19 November 2019, III SA/Gl 817/19, LEX 2745730). However, it is assumed that the period of unfitness for service after the decision has been issued does not have to be additionally confirmed by a certificate within the meaning of Art. 55 of the Act of 25 June 1999. The judicature rightly emphasizes that the nature of a judgment does not only come down to an administrative decision. It is also a statement of knowledge about the health of the policeman, which states that he is permanently incapable of service due to illness. Therefore, since it is concluded that an officer is permanently unfit for duty, it is pointless to request a medical certificate stating that an officer is temporarily unfit for duty due to illness (judgment of the Supreme Administrative Court of 19 December 2019, I OSK 1392/19, LEX 2799499).

From the point of view of the analysis of the issue of the existence of the condition for compulsory dismissal of a police officer from service, it does not matter whether a specific, one disease was the basis for the police officer's absence, or whether during that period he was affected by various ailments constituting a premise justifying his absence. The above conclusion is justified by the application of the lege non distinguente argument, and confirmed on the basis of the judicature (judgment of the Supreme Administrative Court of 26 October 2006, I OSK 299/06, LEX 281381). Periods of absence interrupted by periods of service are not added up (resolution of the Supreme Administrative Court of 26 June 2014, I OPS 16/13, ONSAiWSA 2015, No. 1, item 6). The exception is the situation where the termination of the service relationship takes place at the request of an officer.

In the judicature, the issue of the relationship between the provisions of the Police Act in the scope constituting the obligatory nature of dismissal from service in Art. $41 \mathrm{sec} .1$ cases, and the obligation to consult the termination of the employment relationship, the grounds of which are found in individual acts-for example in 
Art. $22 \mathrm{sec} .2$ of the Act of 5 June 1998 on poviat self-government (Dz.U. 2020, item 920 consolidated text). In this respect, the Supreme Administrative Court commented in the judgment of 22 May 2002 (II SA 668/02, LEX 142350), correctly arguing that the councillor's employment relationship is protected. As the employment relationship of a police officer is an administrative-legal relationship-it is not subject to the protection provided for in the above-mentioned provision (see also judgment of the Supreme Administrative Court of 5 March 1997, II SA 1260/96, ONSA 1998, No. 1, item 18).

At the end of the considerations, it is worth emphasizing that, beyond the meaning of the disposition of the norm expressed in Art. $41 \mathrm{sec} .1$ of the Police Act, there are cases of long-term absence of an officer due to illness, if the commission's decision on permanent incapacity for service has not been issued. Such cases do not fulfil the substantive legal conditions for the above-mentioned legal basis for the exemption (Art. $41 \mathrm{sec} .2$ point 7 of the Police Act).

\section{Immediate enforceability}

The decision to dismiss from service may be made immediately enforceable under Art. 108 of the Code of Administrative Procedure. The legislator provides that invalid decisions may be made immediately enforceable in a situation where it is necessary to protect human health or life or to protect the national farm against heavy losses or due to other social interest or extremely important interests of the parties. The interest of the service treated should be equated with the public interest, which boils down to the need to provide the organizational units of the Police with an appropriate staffing that is capable of carrying out the current tasks and needs of the service. Bearing in mind the above, when an officer loses the ability to perform service in this formation, it should be assumed that it will be justified and justified to say that he should not remain in it longer than indicated by the legislator in Art. 43 sec. 1 of the Police Act.

\section{Ending}

The inability to perform the service by a police officer confirmed by a medical commission's decision is an obligatory condition for terminating the employment relationship. The legislator did not leave any scope of discretion in making a decision on dismissal from service in the event of the above-mentioned condition.

In one of its judgments, the Supreme Administrative Court states that failure to perform official duties by a police officer for a period of more than 12 months may adversely (in the broad sense of the term) affect the fulfilment by his organizational unit of statutory tasks belonging to the Police (judgment of the Supreme Administrative Court of 11 March 2011, I OSK 1610/10, LEX 795213). 
The above thesis indicates a broader context and justification for the statutory obligation to terminate the employment relationship in the event of a long absence due to illness and the related permanent incapacity to perform the service by an officer.

\section{References}

Korcz-Maciejko A. (2013) Prawny charakter rozkazu personalnego, "Administracja: Teoria, dydaktyka, praktyka," nr 3(32).

\section{Court sentences}

Judgment of the Supreme Administrative Court of 5 March 1997, II SA 1260/96, ONSA 1998, No. 1, item 18.

Judgment of the Supreme Administrative Court of 22 May 2002, II SA 668/02, LEX 142350. Judgment of the Supreme Administrative Court of 26 October 2006, I OSK 299/06, LEX 281381. Judgment of the Supreme Administrative Court of 11 March 2011, I OSK 1610/10, LEX 795213. Judgment of the Voivodeship Administrative Court in Lublin of 19 July 2011, III SA/Lu 196/11, LEX 853004.

Judgment of the Supreme Administrative Court of 18 February 2016, I OSK 2849/14, LEX 2080560.

Judgment of the Voivodeship Administrative Court in Warsaw of 31 January 2018, II SA/Wa 1069/17, LEX 2491821.

Judgment of the Voivodeship Administrative Court in Łódź of 24 May 2019, III SA/Łd 189/19, LEX 2679202.

Judgment of the Voivodeship Administrative Court in Gliwice of 19 November 2019, III SA/ Gl 817/19, LEX 2745730.

Judgment of the Supreme Administrative Court of 20 November 2019, I OSK 3291/18, LEX 2768821.

Judgment of the Supreme Administrative Court of 19 December 2019, I OSK 1392/19, LEX 2799499.

Resolution of the Supreme Administrative Court of 26 June 2014, I OPS 16/13, ONSAiWSA 2015, No. 1, item 6.

\section{Legal acts}

The Act of 14 June 1960 Code of Administrative Procedure, Dz.U. 2021, item 735 consolidated text.

The Labour Code Act of 26 June 1974, Dz.U. 2020, item 1320 consolidated text.

The Act of 6 April 1990 on the Police, Dz.U. 2020, item 360 consolidated text.

The Act of 12 October 1990 on the Border Guard, Dz.U. 2020, item 305 consolidated text.

The Act of 24 August 1991 on the State Fire Service, Dz.U. 2020, item 1123 consolidated text. 
The Act of 5 June 1998 on poviat self-government, Dz.U. 2020, item 920 consolidated text.

The Act of 25 June 1999 on cash benefits from social insurance in the event of sickness and maternity, Dz.U. 2021, item 1133 consolidated text.

The Act of 28 November 2014 on medical boards subordinate to the minister competent for internal affairs, Dz.U. 2020, item 398 consolidated text.

The Act of 1 December 2017 amending certain acts in the field of occupational health and safety, Dz.U. 2016, item 1955.

The Ordinance of the Minister of the Interior of 9 July 1991 on the properties and procedure of medical boards subordinate to the Minister of the Interior, Dz.U. 1991, No. 79, item 349.

The Ordinance of the Minister of the Interior of 14 May 2013 on the detailed rights and obligations and the course of police service, Dz.U. 2020, item 1113 consolidated text.

The Ordinance of the Minister of the Interior of 19 December 2014 on medical boards subordinate to the minister competent for internal affairs, Dz.U. 2014, item 1894.

The Ordinance of the Prime Minister of 7 January 2015 on adjudication by medical boards reporting to the Head of the Internal Security Agency and the Head of the Foreign Intelligence Agency, Dz.U. 2015, item 47. 